\section{Original researches}

Received: 23 April 202

Revised: 11 May 2021

Accepted: 28 May 2021

Bila Tserkva National Agrarian University, 8/1, Soborna Sq., Bila Tserkva, Kyiv region, 09117 , Ukraine

Tel.: +38-097-431-88-30

E-mail: godivlya@ukr.net

Stepan Gzhytskyi National University of Veterinary Medicine and Biotechnologies, 50, Pekarska Str., Lviv, 79010, Ukraine

Tel.: +38-097-431-88-30

E-mail: yurikropyvka@gmail.com

Cite this article: Bomko, V. S., \& Kropyvka, Yu. G. (2021). Use of mixed ligand complexes of Zinc, Manganese and Cobalt in feeding highly productive cows during the late dry period. Theoretical and Applied Veterinary Medicine, 9(2), 87-92. doi: $10.32819 / 2021.92014$

\section{Use of mixed ligand complexes of Zinc, Manganese and Cobalt in feeding highly productive cows during the late dry period}

\author{
V. S. Bomko*, Yu. G. Kropyvka** \\ *Bila Tserkva National Agrarian University, Bila Tserkva, Ukraine \\ **Stepan Gzhytskyi National University of Veterinary Medicine and Biotechnologies, Lviv, \\ Ukraine
}

Abstract. The results of establishing the optimal feeding doses of Zinc, Manganese, and Cobalt in the form of their mixed-ligand complexes for high-yielding cows of Holstein, Ukrainian RedSpotted and Ukrainian Black-Spotted dairy breeds during the late dry period were presented, their influence on the future productivity and reproductive qualities of cows were also determined. It was found that lower doses of mixed-ligand complexes of Zinc, Manganese, and Cobalt in the feed mixture stimulated its consumption better. The cows of the 4th experimental group consumed more of the feed mixture, where the concentration of Zinc and Manganese was $35 \mathrm{mg}$, and Cobalt -0.49 $\mathrm{mg}$ per $1 \mathrm{~kg}$ of DM. At various doses of mixed-ligand complexes of Zinc, Manganese, and Cobalt, the increase in live weight in cows of the control group was $24.3 \mathrm{~kg}$, and in the experimental groups, it ranged from $23.7 \mathrm{~kg}$ to $26.9 \mathrm{~kg}$, which is $8.6 \%$ and $10.7 \%(\mathrm{P}<0,05)$ more in the $3 \mathrm{rd}$ and 4 th groups compared with the control. A decrease in the concentration of mixed-ligand complexes of Zinc, Manganese, and Cobalt in the diets of dry cows in the experimental groups by 10, 20,30 and $40 \%$ had a positive effect on their further milk productivity. During the first 100 days of lactation, they milked $60-180 \mathrm{~kg}$ of milk more compared to the control with an increase in fat content by $0.01-0.05 \%$. Also, in the milk of experimental group's cows, compared with the control, the protein content increased $(3.22-3.23 \%$ versus $3.14 \%$ ), and the feed costs per $1 \mathrm{~kg}$ of milk in them were lower by 3.5-9.4\%. Smaller doses of zinc, manganese, and cobalt contributed better to lengthening the period of prolonged action of their mixed-ligand complexes on the body of lactating cows. The calves' live weight at the birth in the 4th experimental group exceeded the indicator of their peers from the control group by $2.3 \mathrm{~kg}$ or $8.81 \%$, while the calves obtained from cows of the $2 \mathrm{nd}$ experimental group prevailed the control by $1.6 \mathrm{~kg}$, or $6,13 \%$, from the $3 \mathrm{rd}$ experimental group - by $1.8 \mathrm{~kg}$, or $6.90 \%$, and the 4th experimental group - by $1.7 \mathrm{~kg}$, or $6.51 \%$. The duration of the service period in all experimental groups of cows was within the recommended norms and was 87.8 days in the control group, and the $2 \mathrm{nd}$, 3rd, 4th and 5th experimental groups, respectively 84.7 days, 82.2 ; 80.6 and 83.5 days, respectively, and there was less in control by $3.1-7.1$ days or $3.3-8.2 \%$. The insemination index in the cows' control group was 1.5 , and in the experimental one $-1.2-1.4$, which is $6.7-20.0 \%$ less.

Keywords: microelements; cows; feed consumption; live weight; milk productivity; reproductive function.

\title{
Використання змішанолігандних комплексів Цинку, Мангану й Кобальту в годівлі високопродуктивних корів у пізній сухостійний період
}

\section{В. С. Бомко*, Ю. Г. Кропивка**}

*Білоцерківський національний аграрний університет, м. Біла Церква, Україна

**Львівський національний університет ветеринарної медицини та біотехнологій імені С. 3. ґжицького, м. Львів, Україна

\footnotetext{
Анотація. Наведено результати встановлення оптимальних доз згодовування Цинку, Мангану та Кобальту у вигляді змішанолігандних комплексів високопродуктивним коровам голштинської, української червоно-рябої та української чорно-рябої молочних порід у пізній сухостійний період, визначено їх уплив на майбутню молочну продуктивність і відтворювальні якості корів. Встановлено, що менші дози змішанолігандних комплексів Цинку, Мангану й Кобальту в кормосуміші, стимулювали краше ії споживання. Найбільше споживали кормосуміш корови 4-ї дослідної групи, де концентрація Цинку й Мангану становила 35 мг, а Кобальту - 0,49 мг на 1 кг сухої речовини. За різних доз змішанолігандних комплексів Цинку, Мангану й Кобальту збільшення живої маси в корів контрольної групи становило 24,3 кг, а у дослідних групах воно коливалося від 23,7 кг до 26,9 кг, що на 8,6\% і 10,7\% (P < 0,05) більше у 3-й і 4-й групах порівняно з контролем. Зменшення концентрації змішанолігандних комплексів Цинку, Мангану і Кобальту в раціонах сухостійних корів дослідних груп на 10, 20, 30 і 40\% позитивно вплинуло на подальшу їх молочну продуктивність. За перші 100 днів лактації від них надоєно на 60-180 кг молока більше порівняно з контролем при збільшенні вмісту жиру на 0,01-0,05\%. Також у мо-
} 
лоці корів дослідних груп порівняно з контролем зростав вміст білка (3,22-3,23\% проти 3,14\%), а витрати кормів на 1 кг молока у них були менші на 3,5-9,4\%. Менші дози Цинку, Мангану і Кобальту краще сприяли подовженню періоду пролонгованої дії їх змішанолігандних комплексів на організм лактуючих корів. Жива маса телят при народженні четвертої дослідної групи перевищувала показник своїх ровесників 3 контрольної групи на 2,3 кг або 8,81\%, тоді як телята, отримані від корів 2-ї дослідної групи, переважали контроль на 1,6 кг, або 6,13\%, 3-ї дослідної групи - на 1,8 кг, або 6,90\% і 4-ї дослідної групи - на 1,7 кг, або 6,51\%. Тривалість сервіс-періоду в усіх піддослідних групах корів знаходилася у межах рекомендованих норм і становила у контрольній групі 87,8 днів, а 2-й, 3-й, 4-й і 5-ї дослідних групах, відповідно 84,7 днів, 82,2; 80,6 і 83,5 днів та була меншою за контроль на 3,1-7,1 днів, або 3,3-8,2\%. Індекс осіменіння в контрольній групі корів складав 1,5, а в дослідних - 1,2-1,4, що на 6,7-20,0\% менше.

Ключові слова: мікроелементи; корови; споживання кормів; жива маса; молочна продуктивність; відтворювальна здатність

\section{Вступ}

При годівлі високопродуктивних корів повнораціонними кормосумішами протягом року, значну роль у підвищенні їх біологічної повноцінності відіграють такі мікроелементи як Купрум, Манган, Цинк, Кобальт, Йод, Селен. При нестачі вище вказаних мікроелементів порушується обмін речовин і синтез білка в організмі корів, погіршується їх стан здоров'я, різко знижується відтворювальна здатність, а також генетично запрограмований, визначений породними особливостями потенціал високої продуктивності. Такі зміни розвиваються як у матері, так і в організмі приплоду (Gallo-Torres, 1972; Andrews, 2000).

На теперішній час нестачу мікроелементів для тварин покривають за рахунок їх сульфатних і хлоридних сполук (Kulyk et al., 1995; Klitsenko et al., 2001), засвоєння яких організмом становить 5-25\% (Grabovenskij et al., 1979), а решта виводиться 3 організму з калом та сечею, що призводить до забруднення навколишнього середовища. Введення в раціони корів мікроелементів у формі халатних сполук, засвоєння їх організмом тварин підвищується до 90-95\% (Hryban et al., 2004; Yefimov, 2005).

Мінеральні речовини беруть активну участь у всіх обмінних процесах в організмі корів, тому при їх нестачі відбуваються порушення та функціональні зміни в організмі тварин, що призводить до різних захворювань та зниження продуктивностi (Klitsenko et al., 2001; Ibatullin \& Holubiev, 2017; Levitskaya, 2017; Kropyvka \& Bomko, 2020), крім цього, знижується використання кормового протеїну, загальне споживання кормів також зменшується (Hellman \& Carlson, 2003; Hnoievyi, 2006; Kulibaba et al., 2017).

Життєдіяльність, рівень обмінних процесів, резистентність, продуктивність, відтворна здатність високопродуктивних корів залежать, поряд із генетичними задатками, від надходження із зовнішнього середовища з кормами біологічно активних речовин (Svezhencov \& Kozyr, 1999; Sorokyn et al., 1982; Sudakov et al., 1991; Stoljarchuk et al., 2000; Zhu et al., 2000). При визначенні норм згодовування біологічно активних речовин високопродуктивним коровам мають враховуватись оптимальні потреби організму, а також комбінації внесених компонентів цих речовин, щоб запобігти негативному впливу високих концентрацій деяких з них або їх дефіциту на організм сільськогосподарських тварин та птиці (Chumachenko \& Stojanovskyj, 1989; Kinal et al., 2008; Kulibaba et al., 2017; Bomko et al., 2018a).

Тому метою дослідження було з'ясування оптимальних доз згодовування Цинку, Мангану та Кобальту у вигляді їх змішанолігандних комплексів високопродуктивним коровам голштинської, української червоно-рябої молочної і української чорно-рябої молочної порід у пізній сухостійний період та їх вплив на майбутню молочну продуктивність і відтворювальні якості корів.

\section{Матеріал і методи досліджень}

Експериментальні дослідження проводили в ТДВ «Терезине» Білоцерківського району Київської області на відібраних за принципом аналогів високопродуктивних коровах голштинської, української червоно-рябої та української чорно-рябої молочних порід. Тварини для досліду були відібрані на 20-25-й день сухостійного періоду після другої лактації і розділені на п'ять груп по 10 голів у кожній - одну контрольну й чотири дослідні.

Відібраних корів, як у другу половину сухостійного періоду, так і в перші 100 днів лактації, годували малокомпонентними кормосумішками, до складу яких уводили: сіно вико-вівсяне

Таблиця 1 - Схема науково-господарського досліду, $\mathrm{n}=10$

\begin{tabular}{|c|c|}
\hline Група & Досліджуваний фактор \\
\hline 1 контрольна & $\begin{array}{l}\text { КС + змішанолігандні комплекси Цинку, Мангану, Кобальту + Суплекс Se й сульфат купруму та йодид } \\
\text { калію. В } 1 \text { кг СР міститься, мг: Цинку - 50; Мангану - 50; Кобальту }-0,7 \text {; Селену }-0,3 ; \text { Купруму - } 10 \text { i } \\
\text { Йоду - 0,7. }\end{array}$ \\
\hline 2 дослідна & $\begin{array}{l}\text { КС + змішанолігандні комплекси Цинку, Мангану, Кобальту + Суплекс Se й сульфат купруму та йодид } \\
\text { калію. В } 1 \text { кг СР міститься, мг: Цинку - 45; Мангану - 45; Кобальту }-0,63 \text {; Селену }-0,3 ; \text { Купруму - } 10 \text { i } \\
\text { Йоду - 0,7. }\end{array}$ \\
\hline 3 дослідна & $\begin{array}{l}\text { КС + змішанолігандні комплекси Цинку, Мангану, Кобальту + Суплекс Se й сульфат купруму та йодид } \\
\text { калію. В } 1 \text { кг СР міститься, мг: Цинку - 40; Мангану - 40; Кобальту }-0,56 \text {; Селену }-0,3 ; \text { Купруму - } 10 \text { i } \\
\text { Йоду - 0,7. }\end{array}$ \\
\hline 4 дослідна & $\begin{array}{l}\text { КС + змішанолігандні комплекси Цинку, Мангану, Кобальту + Суплекс Se й сульфат купруму та йодид } \\
\text { калію. В } 1 \text { кг СР міститься, мг: Цинку - 35; Мангану - 35; Кобальту }-0,49 ; \text { Селену }-0,3 ; \text { Купруму - } 10 \text { i } \\
\text { Йоду - 0,7. }\end{array}$ \\
\hline 5 дослідна & $\begin{array}{l}\text { КС + змішанолігандні комплекси Цинку, Мангану, Кобальту + Суплекс Se й сульфат купруму та йодид } \\
\text { калію. В } 1 \text { кг СР міститься, мг: Цинку - 30; Мангану - 30; Кобальту - 0,42; Селену - 0,3; Купруму - } 10 \text { i } \\
\text { Йоду - 0,7. }\end{array}$ \\
\hline
\end{tabular}


- 4 кг, сінаж злаково-бобовий - 10 кг, силос кукурудзяний - 10 кг, мелясу - 2 кг, комбікорм-концентрат - 4 кг, сіль кухонну 0,19 кг, знефторений фосфат - 0,18 кг.

Кормосуміш (КС) була дефіцитна на Цинк, Купрум, Кобальт, Манган, Йод та Селен. Для покриття дефіциту мікроелементів уводили премікс. Дефіцит Цинку, Мангану й Кобальту ліквідували за рахунок різних рівнів їх змішанолігандних комплексів. Нестачу Купруму покривали його сульфатом, Йоду - йодидом калію на $100 \%$ до норми, а Селену - Суплексом селену, 3 розрахунку 0,3 мг/кг сухої речовини $(\mathrm{CP})$.

За рахунок преміксу в одному кілограмі СР кормосуміші для сухостійних корів 1-ї контрольної групи містилось Цинку і Мангану - 50 мг, а Кобальту - 0,7 мг. У 2-й, 3-й, 4-й і 5-й дослідних групах концентрація цих мікроелементів була нижчою у порівнянні з контролем на 10\%, 20, 30 і 40\% відповідно. Схема досліду наведена в таблиці 1 .

\section{Результати}

Сухостійним коровам у підготовчий і дослідний періоди згодовували 30 кг кормосуміші. Споживання кормосуміші в другій половині сухостійного періоду піддослідними коровами наведено в таблиці 2.

У другій половині сухостійного періоду піддослідні корови споживали в середньому за добу 24,0-25,5 кг кормосуміші (табл. 2). При цьому необхідно відзначити, що менші дози змішанолігандних комплексів Цинку, Мангану й Кобальту в кормосуміші, стимулювали краще ії споживання. Найбільше споживали кормосуміш корови 4-ї дослідної групи, де концентрація Цинку й Мангану становила 35 мг, а Кобальту - 0,49 мг на 1 кг СР. Збільшення поїдання кормосуміші, на нашу думку, пов'язане 3 кращою перетравністю поживних речовин та їх засвоєнням організмом корів.

Таблиця 2 - Раціони годівлі сухостійних корів живою масою 600 кг, плановий надій 8000 кг молока

\begin{tabular}{|c|c|c|c|c|c|}
\hline \multirow{3}{*}{ Показники } & \multicolumn{5}{|c|}{ Група } \\
\hline & \multirow{2}{*}{$\begin{array}{c}\text { контрольна } \\
1\end{array}$} & \multicolumn{4}{|c|}{ дослідна } \\
\hline & & 2 & 3 & 4 & 5 \\
\hline Кормосуміш, кг & 24,0 & 24,5 & 25,0 & 25,5 & 24,0 \\
\hline \multicolumn{6}{|c|}{ У раціоні міститься } \\
\hline Кормові одиниці, кг & 12,24 & 12,43 & 12,62 & 12,91 & 12,24 \\
\hline Обмінна енергія, МДж & 132,62 & 134,56 & 136,51 & 139,75 & 132,62 \\
\hline Суха речовина, кг & 12,54 & 12,75 & 12,96 & 13,25 & 12,54 \\
\hline Сирий протеїн, г & 2196,44 & 2226,84 & 2257,24 & 2312,11 & 2196,44 \\
\hline Легкорозчинна фракція сирого протеїну, г & 1511,57 & 1532,47 & 1553,37 & 1591,22 & 1511,57 \\
\hline Важкорозчинна фракція сирого протеїну, г & 684,87 & 694,37 & 703,87 & 720,89 & 684,87 \\
\hline Перетравний протеїн, г & 1660,8 & 1680,2 & 1699,7 & 1743,4 & 1660,8 \\
\hline Лізин, г & 108,3 & 109,65 & 111,0 & 113,8 & 108,3 \\
\hline Метіонін, г & 67,59 & 68,32 & 69,05 & 70,87 & 67,59 \\
\hline Триптофан, г & 35,77 & 36,11 & 36,45 & 37,44 & 35,77 \\
\hline Сира клітковина, г & 2702,56 & 2799,15 & 2895,90 & 2927,93 & 2702,56 \\
\hline Крохмаль, г & 1074,8 & 1079,1 & 1083,4 & 1116,6 & 1074,8 \\
\hline Цукор, г & 1686,4 & 1696,1 & 1705,9 & 1756,3 & 1686,4 \\
\hline Сирий жир, г & 698,2 & 705,5 & 712,9 & 731,8 & 698,2 \\
\hline Сіль кухонна, г & 68 & 68 & 68 & 68 & 68 \\
\hline Кальцій, г & 94,1 & 97,3 & 100,5 & 101,7 & 94,1 \\
\hline Фосфор, г & 55,83 & 56,38 & 56,93 & 58,18 & 55,83 \\
\hline Сірка, г & 24,56 & 24,90 & 25,23 & 25,85 & 24,56 \\
\hline Купрум, мг & 145 & 145 & 145 & 145 & 145 \\
\hline Цинк, мг & 730 & 657 & 584 & 511 & 438 \\
\hline Манган, мг & 730 & 657 & 584 & 511 & 438 \\
\hline Кобальт, мг & 10,2 & 9,18 & 8,16 & 7,14 & 6,13 \\
\hline Йод, мг & 10,2 & 10,2 & 10,2 & 10,2 & 10,2 \\
\hline Селен, мг & 8,76 & 8,76 & 8,76 & 8,76 & 8,76 \\
\hline Каротин, мг & 875 & 875 & 875 & 875 & 875 \\
\hline Вітамін D, MO & 17500 & 17500 & 17500 & 17500 & 17500 \\
\hline
\end{tabular}


Таблиця 3 - Молочна продуктивність піддослідних корів ( $\mathrm{n}=10 ; \mathrm{M} \pm \mathrm{m})$

\begin{tabular}{|c|c|c|c|c|c|}
\hline \multirow{3}{*}{ Показники } & \multicolumn{5}{|c|}{ Група } \\
\hline & \multirow{2}{*}{$\begin{array}{c}\text { контрольна } \\
1\end{array}$} & \multicolumn{4}{|c|}{ дослідна } \\
\hline & & 2 & 3 & 4 & 5 \\
\hline $\begin{array}{l}\text { Надій молока на } 1 \text { корову за перші } 100 \\
\text { днів лактації, кг }\end{array}$ & 3190 & 3250 & 3330 & 3370 & 3280 \\
\hline Середньодобовий надій молока, кг & 31,9 & 32,5 & 33,3 & 33,7 & 32,8 \\
\hline Вміст жиру в молоці, \% & $3,71 \pm 0,04$ & $3,72 \pm 0,03$ & $3,74 \pm 0,04$ & $3,76 \pm 0,02$ & $3,75 \pm 0,05$ \\
\hline $\begin{array}{l}\text { Валовий надій молока } 4 \text { \%-вої жирності } \\
\text { на } 1 \text { корову, кг }\end{array}$ & 2958,3 & 3022,5 & 3113,5 & 3167,8 & 3075,0 \\
\hline \pm до контролю, кг & - & $+64,2$ & $+155,2$ & $+209,5$ & $+116,7$ \\
\hline $\begin{array}{l}\text { Середньодобовий надій молока } 4 \text { \%-вої } \\
\text { жирності, кг }\end{array}$ & $29,58 \pm 0,14$ & $30,22 \pm 0,18^{* *}$ & $31,13 \pm 0,20^{* * *}$ & $31,68 \pm 0,19 * * *$ & $30,75 \pm 0,16^{* *}$ \\
\hline \pm до контролю, кг & - & $+0,64$ & $+1,55$ & $+2,10$ & $+1,17$ \\
\hline у \% до контролю & 100,0 & 102,2 & 105,2 & 107,1 & 104,0 \\
\hline Вміст білка в молоці, \% & $3,14 \pm 0,04$ & $3,21 \pm 0,03$ & $3,23 \pm 0,05$ & $3,22 \pm 0,04$ & $3,19 \pm 0,06$ \\
\hline $\begin{array}{l}\text { Витрати кормів на } 1 \text { корову за перші } 100 \\
\text { днів лактації, корм. од. }\end{array}$ & 2514 & 2478 & 2490 & 2439 & 2491 \\
\hline $\begin{array}{l}\text { Витрати кормів на } 1 \text { кг молока } 4 \text { \%-вої } \\
\text { жирності, корм. од. }\end{array}$ & 0,85 & 0,82 & 0,80 & 0,77 & 0,81 \\
\hline у \% до контролю & 100,0 & 96,5 & 94,1 & 90,6 & 95,3 \\
\hline
\end{tabular}

Примітка: ** $-\mathrm{P}<0,01 ; * * *-\mathrm{P}<0,001$ порівняно $з$ контролем.

Після розтелення протягом 10 днів корів годували повнораціонною кормосумішшю сухостійного періоду, а потім проводили їх роздій за рахунок збільшення кількості концентрованих і соковитих кормів, щоб визначити вплив змішанолігандних комплексів Цинку, Мангану і Кобальту не тільки на організм сухостійних корів, а й на їх молочну продуктивність за перші 100 днів лактації (табл. 3).

Зменшення концентрації змішанолігандних комплексів Цинку, Мангану і Кобальту в раціонах сухостійних корів дослідних груп на 10, 20, 30 і 40\% позитивно вплинуло на подальшу їх молочну продуктивність (табл. 3).

За перші 100 днів лактації від кожної корови контрольної групи було надоєно 3190 кг молока натуральної жирності, тоді як від корів дослідних груп на 60-180 кг більше при збільшенні вмісту жиру в молоці на $0,01-0,05 \%$. Внаслідок збільшенням жирності молока та перерахунку валових надоїв натурального молока у молоко 4 \%-ої жирності, різниця за цим показником між коровами контрольної і 2-ї дослідної групи складала 64,2 кг або 2,2\% (P < 0,01), 3-ї дослідної - 155,2 кг, або 5,2\% (P < 0,001), 4-ї дослідної - 209,5 кг, або 7,1\% (Р < 0,001) і 5-ї дослідної групи - 116,7 кг, або 4,0\% (Р <0,01). У молоці корів дослідних груп порівняно з контролем зростав вміст білка (3,22-3,23\% проти $3,14 \%)$. Витрати кормів на 1 кг молока у дослідних групах корів були менші на 3,5-9,4\% порівняно з контролем.

Отже, за даними молочної продуктивності корів за перші 100 днів лактації, можна судити про позитивну післядію змішанолігандних комплексів Цинку, Мангану і Кобальту на організм корів.

Протягом перших 100 днів лактації також вивчати пролонговану дію змішанолігадних комплексів Цинку, Мангану і Кобальту на відтворну їх здатність корів (табл. 4).

Відтворну здатність піддослідних корів оцінювали за живою масою телят при народженні, тривалістю сервіс-періоду та індексом осіменіння. Жива маса телят при народженні четвер-

Таблиця 4 - Відтворна здатність піддослідних корів ( $\mathrm{n}=10 ; \mathrm{M} \pm \mathrm{m})$

\begin{tabular}{|c|c|c|c|c|c|}
\hline \multirow{3}{*}{ Показники } & \multicolumn{5}{|c|}{ Група } \\
\hline & \multirow{2}{*}{$\begin{array}{c}\text { контрольна } \\
1 \\
\end{array}$} & \multicolumn{4}{|c|}{ дослідна } \\
\hline & & 2 & 3 & 4 & 5 \\
\hline Жива маса новонароджених телят, кг & $26,1 \pm 1,3$ & $27,7 \pm 0,8$ & $27,9 \pm 1,2$ & $28,4 \pm 1,1$ & $27,8 \pm 0,9$ \\
\hline \pm до контролю: кг & - & $+1,6$ & $+1,8$ & $+2,3$ & $+1,7$ \\
\hline$\%$ & - & $+6,13$ & $+6,90$ & $+8,81$ & $+6,51$ \\
\hline Тривалість сервіс-періоду, днів & 87,8 & 84,7 & 82,2 & 80,6 & 83,5 \\
\hline 土 до контролю: днів & - & $-3,1$ & $-5,6$ & $-7,2$ & $-4,3$ \\
\hline$\%$ & - & $-3,54$ & $-6,38$ & $-8,21$ & $-4,9$ \\
\hline Індекс осіменіння & 1,5 & 1,4 & 1,3 & 1,2 & 1,4 \\
\hline \pm до контролю & - & $-0,1$ & $-0,2$ & $-0,3$ & $-0,1$ \\
\hline У \% до контролю & 100,00 & 93,33 & 86,66 & 80,00 & 93,33 \\
\hline
\end{tabular}


тої дослідної групи перевищувала показник своїх ровесників 3 контрольної групи на 2,3 кг або 8,81\%, тоді як телята, отримані від корів 2-ї дослідної групи, переважали контроль на 1,6 кг, або 6,13\%, 3-ї дослідної групи - на 1,8 кг, або 6,90\% і 4-ї дослідної групи - на 1,7 кг, або 6,51\%.

Тривалість сервіс-періоду в усіх піддослідних групах корів знаходилася у межах рекомендованих норм і становила у контрольній групі 87,8 днів, а 2-й, 3-й, 4-й і 5-ї дослідних групах, відповідно 84,7 днів, 82,2; 80,6 і 83,5 днів та була меншою за контроль на 3,1-7,1 днів, або 3,3-8,2\%.

Індекс осіменіння в контрольній групі корів складав 1,5 , а в дослідних - 1,2-1,4, що на 6,7-20,0\% менше. При цьому найменша кількість осіменінь на одно запліднення була проведена у 4-й дослідній групі, у раціоні яких концентрація Цинку і Мангану становила 35 мг, а Кобальту 0,49 мг/кг СР. Очевидно, менші дози Цинку, Мангану і Кобальту краще сприяли подовженню періоду пролонгованої дії їх змішанолігандних комплексів на організм лактуючих корів.

\section{Обговорення}

Сьогодні питаннями використання металохелатних комплексів різних мікроелементів займаються (Paccard, 1975; Bomko et al., 2016; Smetanina et al., 2016). Проте матеріалів із використання органічних форм мікроелементів, таких, як змішанолігандні комплекси $\mathrm{Zn}, \mathrm{Co}, \mathrm{Mn}$ в раціонах високопродуктивних корів в промислових комплексах Лісостепу України $є$ недостатньо.

Численними дослідженнями доведено, що тварини можуть адаптуватися до дефіциту мінеральних речовин, особливо мікроелементів (Купруму, Кобальту, Цинку, Йоду, Мангану та інших), але в них порушується обмін речовин і синтез білка, погіршується стан здоров'я, різко знижується відтворювальна здатність, а також генетично запрограмований, визначений породними особливостями потенціал високої продуктивності (Lebedev, 1990; Andrews, 2000; Basonov, 2005).

Частина мінеральних речовин (Калій, Натрій, Кальцій, Магній, Фосфор, Сульфурум та ін.) використовується на будову основних речовин тіла - білків, жирів і вуглеводів та є постійними компонентами протоплазми живих клітин. Ферум, Купрум, Цинк, Манган, Кобальт, Йод та ін. належать до біоактиваторів, “регуляторів" життя - ферментів, гормонів, вітамінів (B12). Дефіцит мінеральних речовин, як і вітамінів, знижує загальне споживання кормів та використання тваринами кормового протеїну (Dmitrochenko \& Moroz, 1971; Hennig, 1976; Mahan, 1990; Bomko et al., 2018b).

Дослідники (Vojnar, 1956; Bomko, 1997; Kokorev et al., 2004; Bokova, 2008; Vorobel \& Pivtorak, 2011; Bomko et al., 2016) довели, що органічні форми мікроелементів мають позитивну дію на тваринний організм. Кращі результати отримують у разі використання комплексних сполук металів 3 амінокислотами або органічними кислотами (лігандами). В такій формі вони легко адсорбуються у кров'яне русло та проникають через мембрану клітин у місця їх локалізації. Використання хелатних комплексів у годівлі тварин позитивно впливає на підвищення продуктивності, крім того, вони є більш перспективними з екологічного погляду.

\section{Висновки}

Найефективніший вплив на кількість спожитої кормосуміші, засвоєння поживних речовин раціонів, динаміку живої маси в пізній сухостійний період, пологові показники, а також на параметри майбутньої молочної продуктивності і відтворювальної здатності високопродуктивних корів мали такі рівні мікроелементів в 1 кг СР кормосуміші: Цинку - 35 мг, Мангану - 35 мг і Кобальту - 0,49 мг за рахунок їх змішанолігандних комплексів.

\section{References}

Andrews A.H. (2000). The Health of Dairy Cattle. London : Blaskwell Science, 359.

Basonov, O. A. (2005). Balans Nitrogena, kal'cija i fosfora u laktirujushhih korov. Zootehnija, 5, 7-8 (in Russian).

Bokova, T. P. (2008). Ispolzovanie biologicheski aktivnyh dobavok $\mathrm{v}$ racione zhivotnyh. Kormlenie Selskohozjajstvennyh Zhivotnyh i Kormoproizvodstvo, 9, 9-10 (in Russian).

Bomko, V. S. (1997). Himichnyj sklad, peretravnist i pozhyvnist povnoracionnyh kormosumishej. Visnyk Bilocerkivs'kogo Derzhavnogo Agrarnogo Universytetu, 3 (1), 113-115 (in Ukrainian).

Bomko, V. S. Danylenko, V. P., \& Povoznikov, M. G. (2016). Pokaznyky vidtvornoi zdatnosti vysokoproduktyvnyh koriv za riznyh rivniv cynku u racionah. Visnyk Agrarnoi Nauky Prychornomorja, 2 (89), 1, 35-43 (in Ukrainian).

Bomko, V. S., Kropyvka, Y. G., \& Bomko, L. G. (2018a). Zinc metabolism in high yielding dairy cows when fed mixedligand complexes of Zinc, Manganese and Cobalt. The Animal Biology, 20(2), 15-23.

Bomko, V., Kropyvka, Yu., Bomko, L., Chernyuk, S., Kropyvka, S., \& Gutyj, B. (2018b). Effect of mixed ligand complexes of Zinc, Manganese, and Cobalt on the Manganese balance in highyielding cows during first 100-days lactation. Ukrainian Journal of Ecology, 8(1), 420-425.

Chumachenko, V. Ju. \& Stojanovskyj, S. V. (1989). Dovidnyk po zastosuvannju biologichno aktyvnyh rechovyn u tvarynnyctvi. Kyiv: Urozhaj, 262 (in Ukrainian).

Dmitrochenko, A. P., \& Moroz, Z. M. (1971). Rol' mineral'nyh veshhestv i vitaminov $\mathrm{v}$ ispol'zovanii proteina. Kormlenie sel'skohozjajstvennyh zhivotnyh: sbornik nauchnyh trudov. L.: Kolos, 9, 91-97 (in Russian).

Gallo-Torres, H. (1972). Vitamin E in animal nutrition. International Journal for Vitamin and Nutrition Research, 42(2), 312-323.

Grabovenskij, I. I., Dyrda, S. A., \& Muljak, V. G. (1979). Mikrojelementy v kormovyh racionah. Uzhgorod: Karpaty (in Russian).

Hellman, H. \& Carlson, M. (2003). Organic and Inorganic Sources of Trace Minerals for Swine Production. Feeding, Universite of Missouri-Columbia, 789-797.

Hennig, A. (1976). Mineral'nye veshhestva, vitaminy, biostimuljatory $\mathrm{v}$ kormlenii sel'skohozjajstvennyh zhivotnyh. Moscow. Kolos (in Russian).

Hnoievyi, V. I. (2006). Hodivlia i vidtvorennia poholivia silskohospodarskykh tvaryn v Ukraini: monohrafiia Kh.: Mahda LtD. (in Ukrainian).

Hryban, V. H., Yefimov, V. H., \& Rokytianskyi, V. M. (2004). Vykorystannia preparativ humusnoi pryrody u poiednanni z mikroelementamy dlia korektsii obminu rechovyn u koriv. Naukovyi visnyk NAU, 78, 64-66 (in Ukrainian).

Ibatullin, I. I., \& Holubiev, M. I. (2017). Effect of feeds containing different sources of manganese on certain carcass parameters of quail. Scientific Messenger of LNU of Veterinary Medicine and Biotechnologies, 19(79).

Yefimov, V. H. (2005). Vplyv hidrohumatu i mikroelementiv na vmist komponentiv nebilkovoho azotu ta aktyvnist transaminaz syrovatky krovi laktuiuchykh koriv. Visnyk Dnipropetrovskoho DAU. 2, 252-254 (in Ukrainian).

Kinal, S., Korniewicz, A., Słupczyńska, M., Bodarski, R., Korniewicz, D., \& Čermák, B. (2008). Effect of the application of bioplexes of zinc, copper and manganese on milk quality and composition of milk and colostrum and some indices of the blood metabolic profile of cows. Czech Journal of Animal Science, 52(12), 423-429. 
Klitsenko, H. T., Kulyk, M. F., Kosenko, M. V. (2001). Mineralne zhyvlennia tvaryn. Kyiv. Svit (in Ukrainian).

Kokorev, V. A., Gurjanov, A. M., \& Prytkov, Ju. N. (2004). Optimizacija mineralnogo pitanija selskohozjajstvennyh zhivotnyh. Zootehnija, 7, 12-16 (in Russian).

Kropyvka, Y. G., \& Bomko, V. S. (2020). Influence of mixedliganding complexes of Zinc, Manganese and Cobalt in feeding highly productive cows in the early dry period for their dairy productivity in the first 100 days of lactation and reproductive functions. Scientific Messenger of LNU of Veterinary Medicine and Biotechnologies, 22(93), 132-136.

Kulibaba, S. V., Dolgaya, M. M., \& Ionov, I. A. (2017). Effect of feeding chelate complexes of trace elements on the average daily balance of $\mathrm{Cu}, \mathrm{Zn}$ and $\mathrm{Mn}$ in the organism of cows during the period of lacta-tion. Scientific Messenger of LNU of Veterinary Medicine and Biotechnologies, 19(79), 58-61.

Kulyk, M. F., Zasukha, T. V., \& Velychko, I. M. (1995). Tradytsiini i netradytsiini mineraly u tvarynnytstvi. Kyiv. Silhosposvita (in Ukrainian).

Lebedev, N. I. (1990). Ispol'zovanie mikrodobavok dlja povyshenija produktivnosti zhvachnyh zhivotnyh. Agropromizdat, 94 (in Russian).

Levitskaya, L. G. (2017). The needs and characteristics of feeding dairy cows. Scientific Messenger of LNU of Veterinary Medicine and Biotechnologies, 19(79), 62-67.

Mahan, D. C. (1990). Mineral nutrition of the sow: a review. Journal of Animal Science, 68(2), 573.

Paccard, P. (1975). Role de certainescarences en oligoelementerdans la subfertilite, constatee chez les la Correre. ElevageInsem, 148, 13-16.
Smetanina, O., Ibatulin, I., \& Bomko, V. (2016). Influence of premixes metal chelate based on the chemical composition of milk of highly productive cows in the first 100 days of lactation. Theoretical and Applied Veterinary Medicine, 4(1), 251-255. (in Ukrainian).

Sorokyn, V. N., Ivanov, V. P., \& Cukanov, V. G. (1982). Vliyanie premiksov razlichnogo sostava na obes pechennost porosjat rannego otema vodorastvorimymi vitaminami. Moscow, 107112 (in Russian).

Stoljarchuk, P. Z., Petryshak, R. A., \& Naumjuk, O. S. (2000). Racionalna godivlja dijnyh koriv u litnopasovyshhnyj period. Silskyj Gospodar, 7-8, 20-21 (in Ukrainian).

Sudakov, M. O., Bereza, V. I., Pogurskyj, I. G. (1991). Mikroelementozy silskogospodarskyh tvaryn. Kyiv. Urozhaj (in Ukrainian).

Svezhencov, A. I. \& Kozyr, B. C. (1999). Osoblyvosti godivli vysokoproduktyvnyh koriv. Dnipropetrovsk (in Ukrainian).

Vojnar, A. O. (1956). Fiziologicheskaja rol mikrojelementov v organizme zhivotnyh i cheloveka $\mathrm{i}$ zadachi issledovanij $\mathrm{v}$ jetom napravlenie. In: Mikrojelementy v selskom hozjajstve i medicine. Riga. Zinatne (in Russian).

Vorobel, M. I., \& Pivtorak, Ja. I. (2011). Znachennja mikroelementiv $\mathrm{u}$ zhyttjedijalnosti tvaryn. Scientific Messenger of LNU of Veterinary Medicine and Biotechnologies, 13(5), 54-60 (in Ukrainian).

Zhu, H., Shipp E., Sanchez, R. J., Liba, A., Stine, J. E., Hart, P. J., Gralla, E. B., Nersissian, A. M., \& Valentine J. S. (2000). Cobalt (2+) binding to human and tomato copper chaperone for superoxide dismutase: implications for the metal ion transfer mechanism. Biochemistry, 39(18), 1513-1521. 